\title{
إخراج الصورة الصحفية في الصفحات الرياضية لليوميات الجزائرية دراسة تحليلية لصحيفة الخبر 2012-2013
}

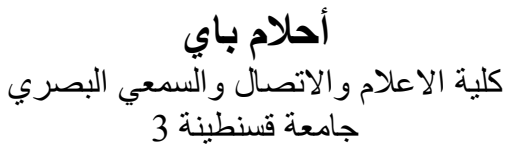

تهدف هذه الدراسة إلى التعرف على أنواع الصور

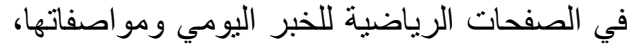

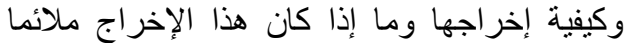

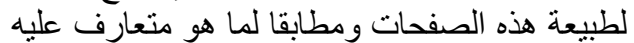

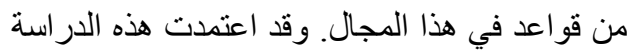

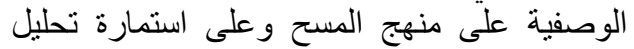

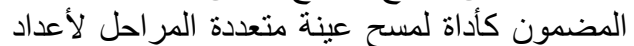

من يومية "الخبر " الجزائرية لسنة 2012-2013.

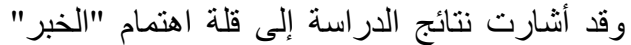

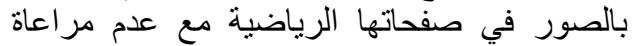

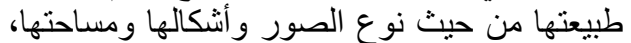
أما إخر اجها من حيث القطع و الموقع والألوان فكان

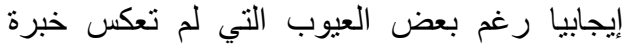
الصحيفة و إمكانياتها المادية.

\section{مقدّمة:}

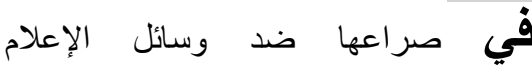

\section{Résumé :}

Cette étude a comme but d'étudier les types de photos parues dans les pages sportives du quotidien arabophone (Alkhbar), d'analyser ses caractéristiques et d'évaluer la teneur de leur mise en page concernant les règles adoptées dans ce domaine. Cette étude descriptive a adopté une méthode d'enquête et d'analyse de contenu d'un échantillon à étapes multiples du quotidien Algérien "Alkhabar" pour l'année 2012-2013.

Les résultats de l'étude ont révélé un manque d'intérêt (quantitatif) pour les images dans les pages sportives et le non-respect des normes concernant le type de photos, de formes, de tailles, et ce a contrario des couleurs, du positionnement, des coupes et de la mise en page des photos qui ont été très appropriés, malgré quelques défauts, qui ne reflètent pas à notre avis la longue expérience et les capacités matérielles du journal. 
حيث سمت بإخر اجها بطرق حيوية ومتتوعة، زيادة على توظيف قدرتها على جذب الانتباه لزيادة

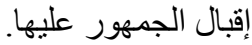

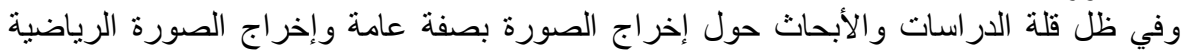

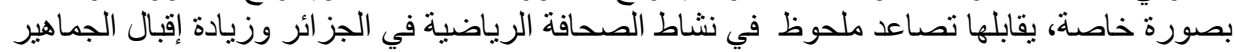

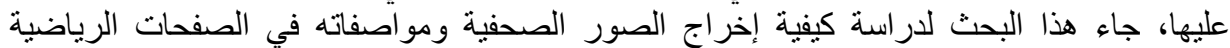

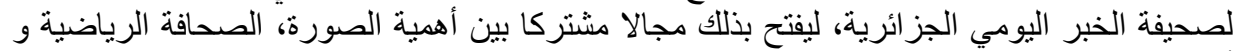

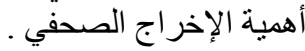

وقد تضمن هذا البحث جزئين رئيسيين؛ شمل الجزء الأول الجئ أدبيات الموضوع متضمنة تعريف

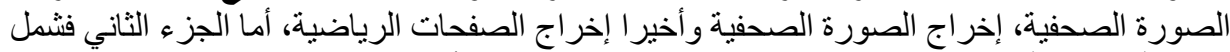

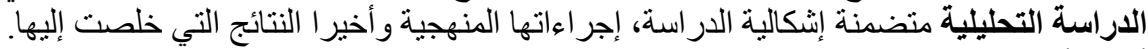

أولا : أدبيات الموضوع: المبرة:

وسنتعرض فيما يلي لتعريف الصورة الصحفية، إخراج الصورة الصحفية وأخيرا إخراج الصفحات

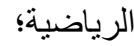

1 - ت تعريف الصورة الصحفية:

يعرف "محمد خليل الراتب" الصورة الصحية: الصحفية بأنها الصور الملتقطة للتدليل على حوادث معينة

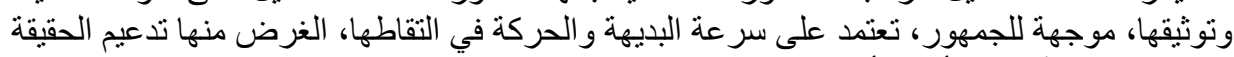
و التعبير عن الآراء والأفكار أما من جانب الثنكل فغرضها جذب الانتباه إلى الموضوع و و إثارة اهتمام

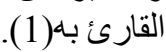

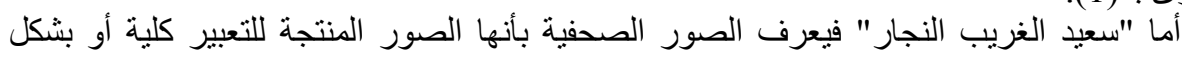

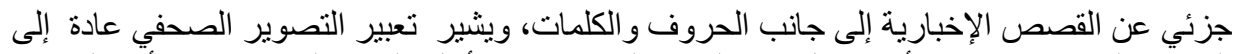

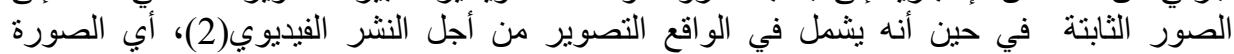

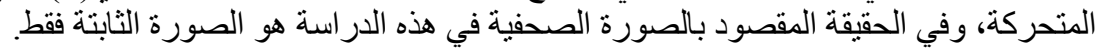

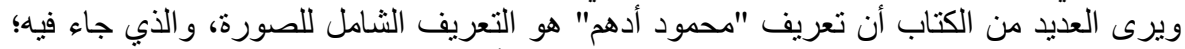

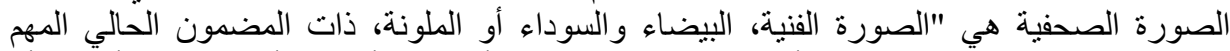

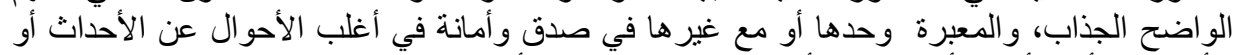

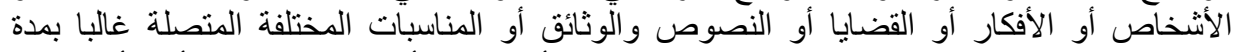

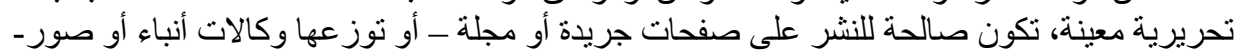

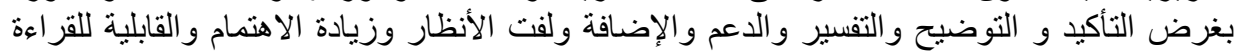

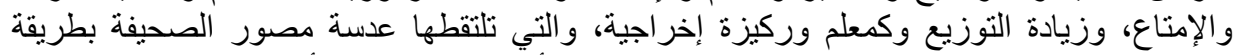

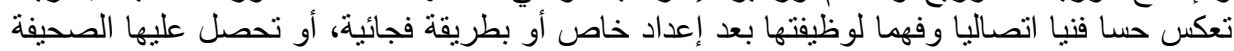

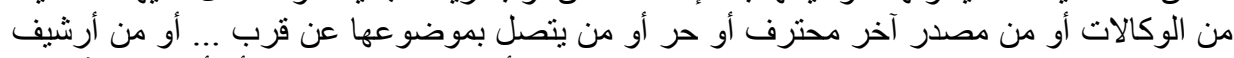

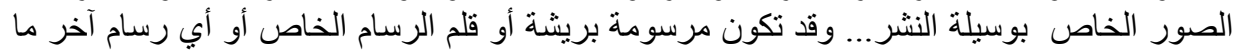

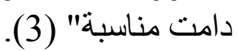

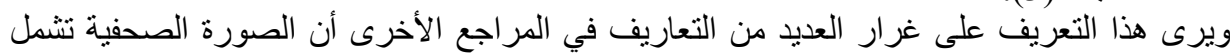

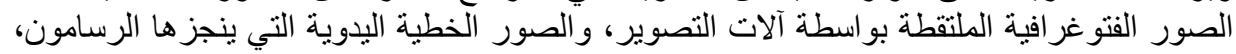

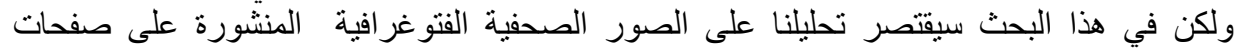

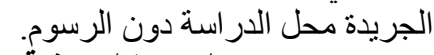

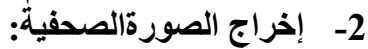

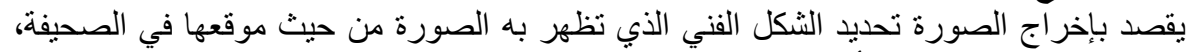

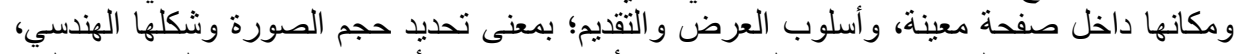

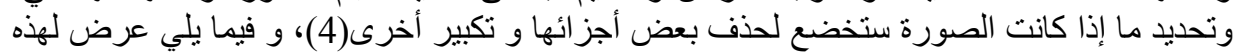
الجو انب تتخلإها جملة من القو اعد و الثروط: 


\section{إخراج الصورة الصحفية في الصفحات الرياضية لليوميات الجزائرية دراسة تحليلية لُصحيفة الخبر الصفات الرياضية لليوميات}

1-2 - اختيار الصورة الصالحة للنشر:

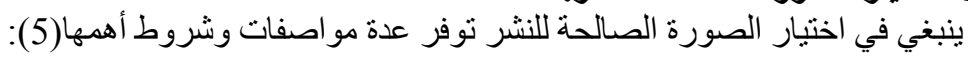

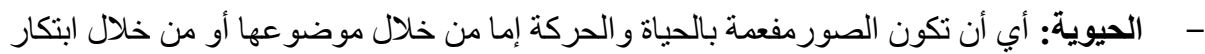

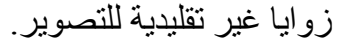

- - التلقائية: أب أن تكون الصور ملتقطة بطريقة فجائية ودون تحضير مسبق.

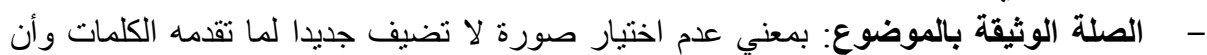

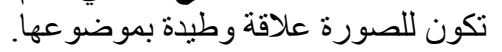
- الجاتب الانساني: أي ان تحمل الصورة قيمة انسانية تحرك مشاعر القراء وتنثير اهتمامهم

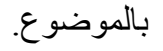
- - الجانب القني: بمعنى أن تكون الصورة و اضحة دقيقة التفاصيل و على قدر عال من التباين. 2-2-2 - 2-2 تحليد موقع الصورة: ويتعلق ذلك بجانبين:

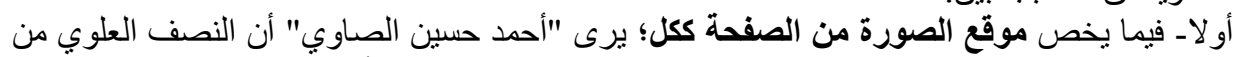

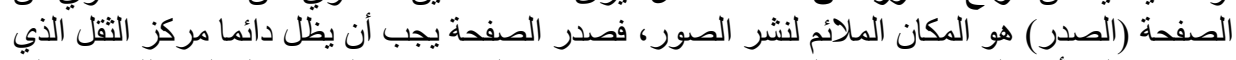

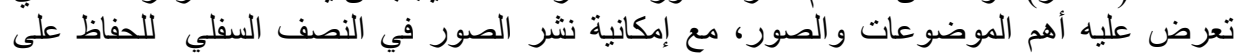

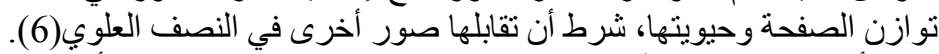

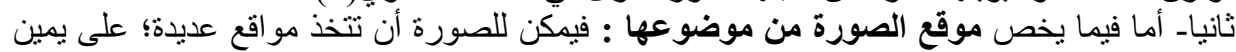

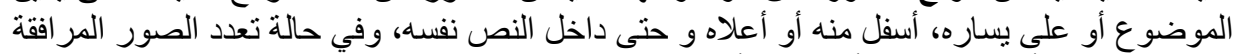

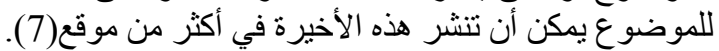

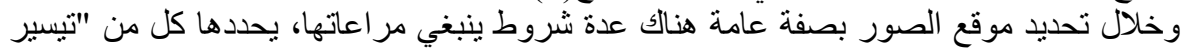

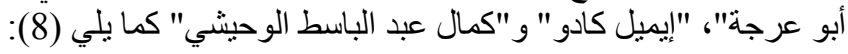

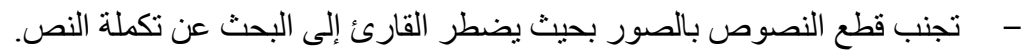

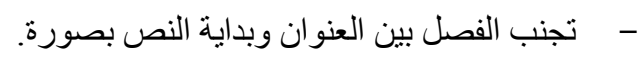
- - تجنب وضع الصورة على طية الصفحة. - تجنب نشر صور الأشخاص الجانبية وهم ينظرون إلى خارج الصفحة حتي لا تثد نظر القارئ بذلك الاتجاه. - تجنب نشر الصور على الصفحة مركزة على جانب واحد فقط. - - عدم وضع الصورة بجانب إعلان مصور حتى لا يخلط القارئ بينهما.

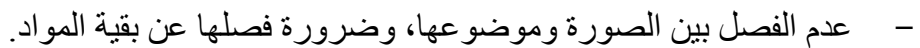
-3-2 - 20 - مساحة الصور

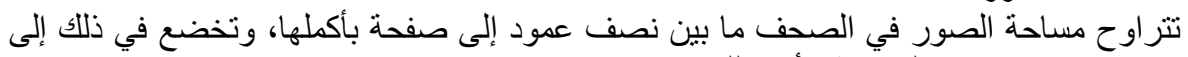

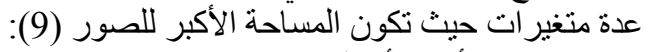

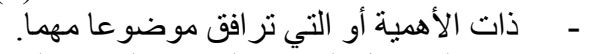

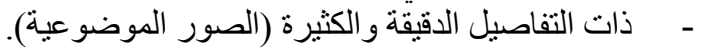

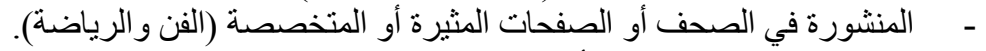

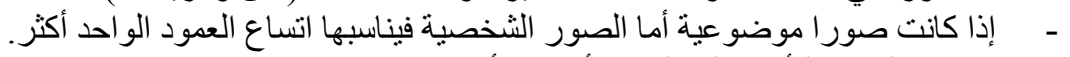

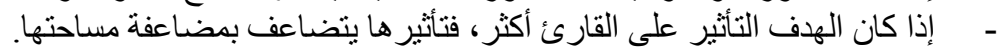

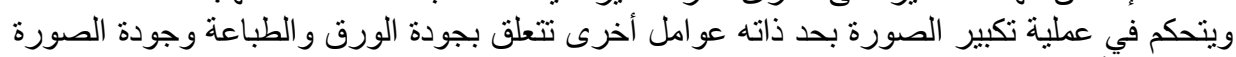
الملتقطة الآصلية (10). 
- 4-2 قطع (قص) الصورة:

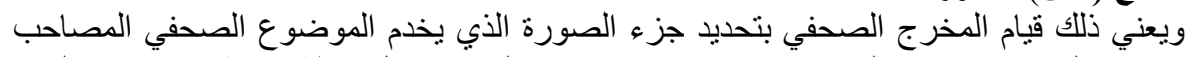

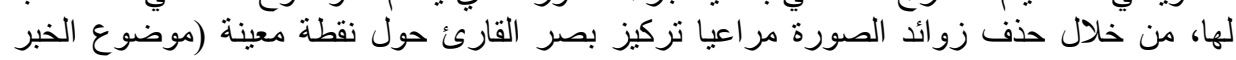

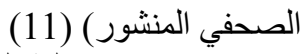

ويجب عند تتفيذ عملية القطع تجنب العيوب التالية (12):

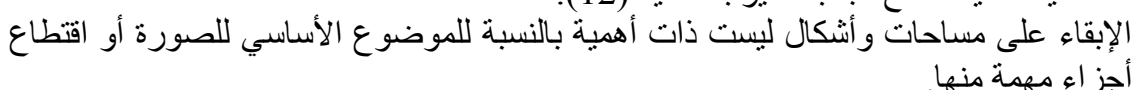

- قطع الصورة بشكل ينجم عنه تغيير اتجاه الحركة للمنظر الظاهر فيها، كأن ينم قطع الصورة بما

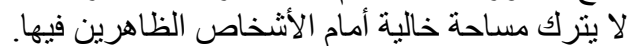

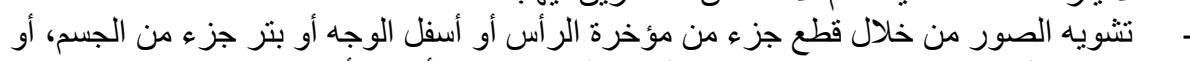

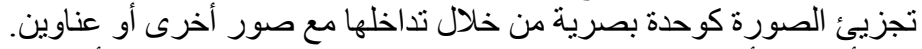

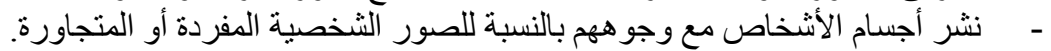

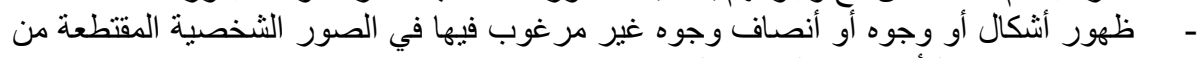

صور موضو عية أو شخصية جماعية.

- إجراء قطع الصور الشخصية المتجاورة بما ينجم عنه اختلاف في أحجام الوجوه من صورة

لأخرى.

- حذف خلفية الصور الثخصية مع الإبقاء على الوجه فقط في حدود الرقبة مما يعطي إحساسا

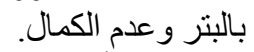

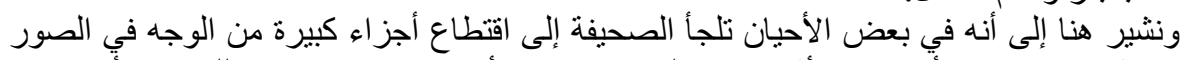

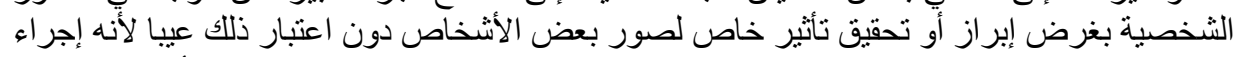

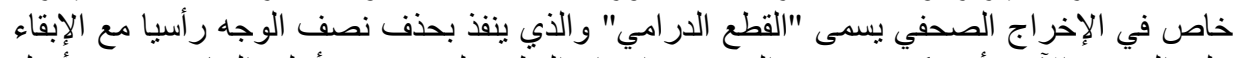

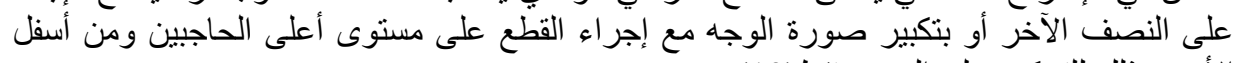

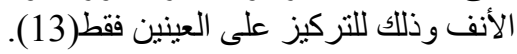

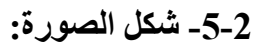

ويقصد به الثنكل الهندسي الذي تظهر به الصورة، وقد يكون أحد الأشكال الآتية (14):

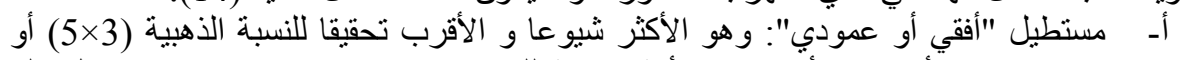

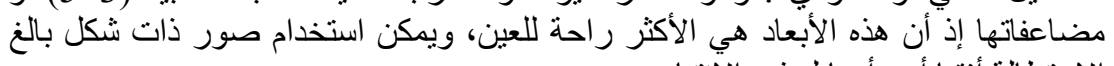

الاسنطالة أفقيا أو رأسيا لجذب الابعاد الآنتباه.

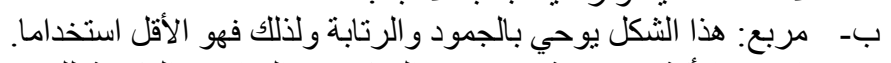

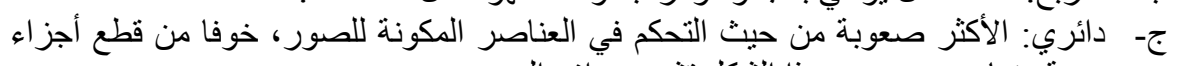

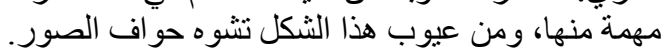

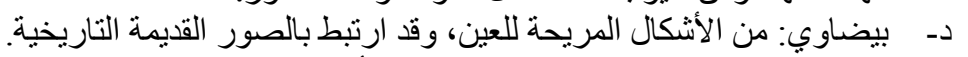

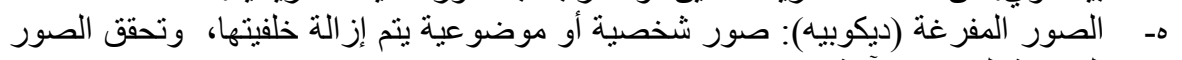

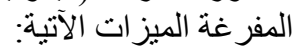

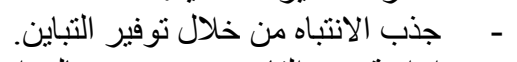

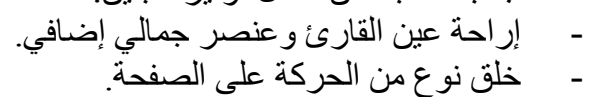

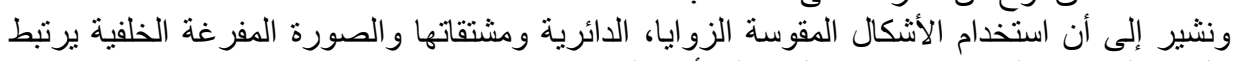

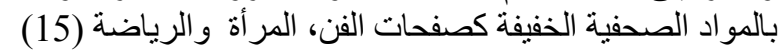
3- 3 إخراج الصفحات الرياضية:

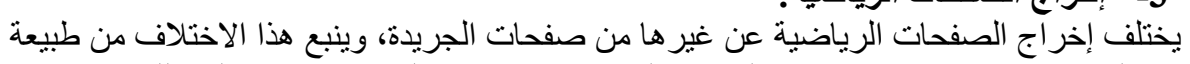

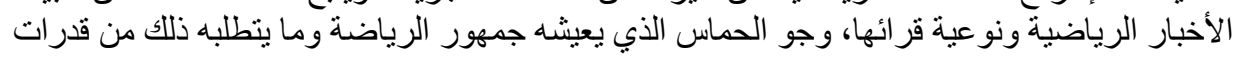




\section{إخراج الصورة الصحفية في الصفحات الرياضية لليوميات الجزائرية

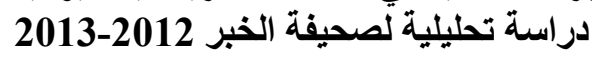

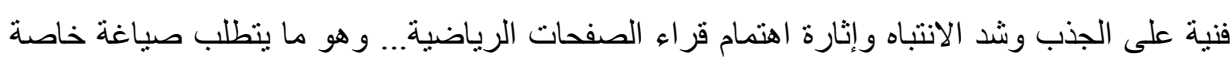

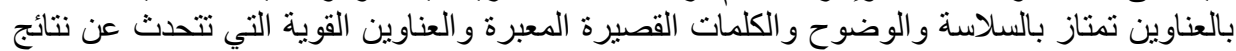

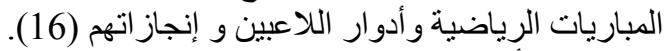

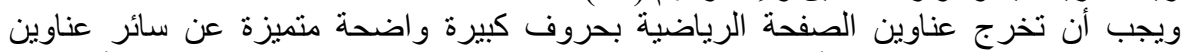

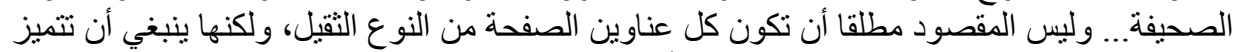

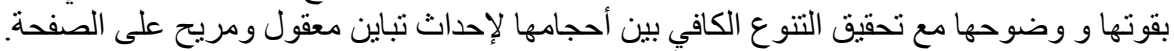

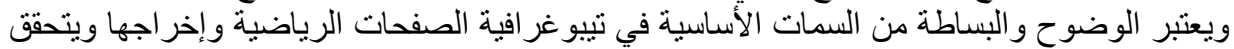

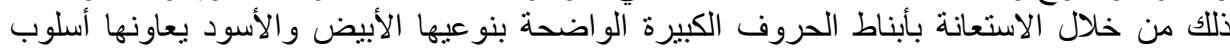

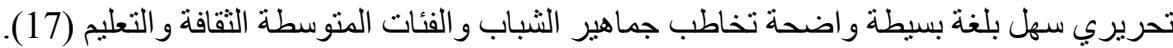

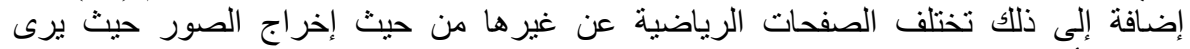

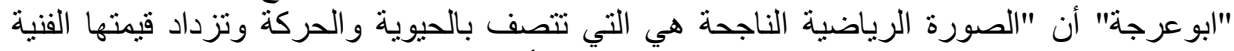

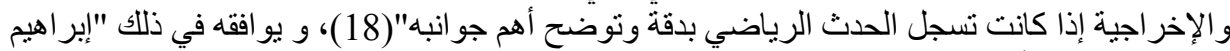

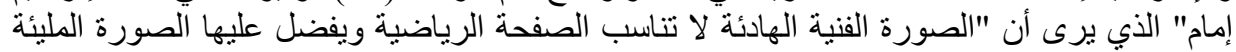

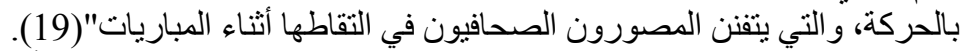

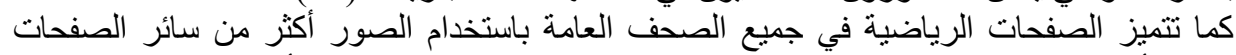

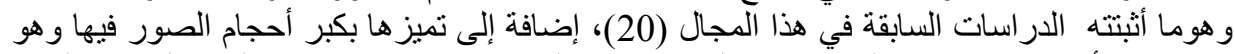

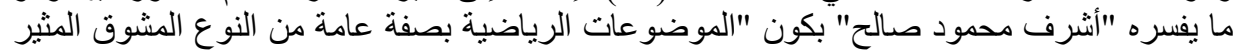

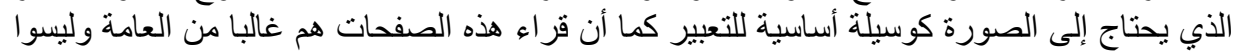

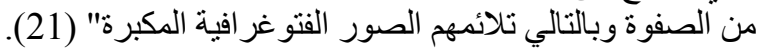

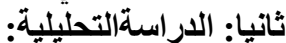

وتتضمن إنثكالية الدراسة، إجر اءاتها المنهجية و أخيرا النتائج التي خلصت إليها.

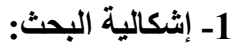

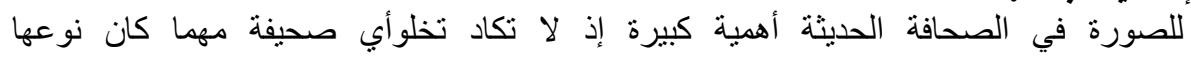

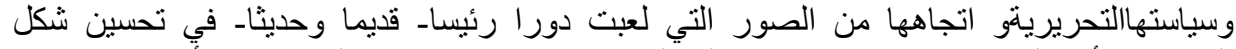

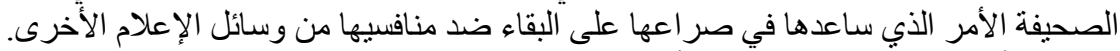

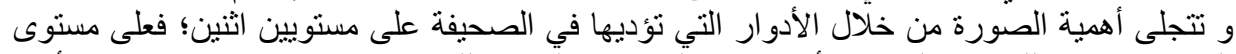

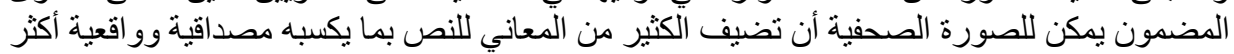

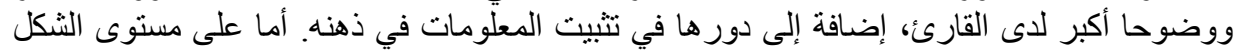

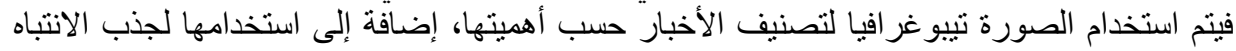

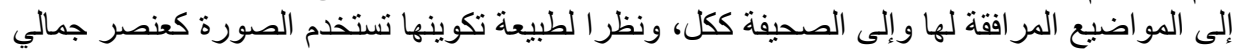

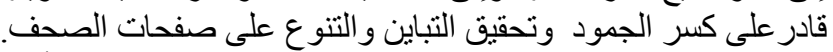

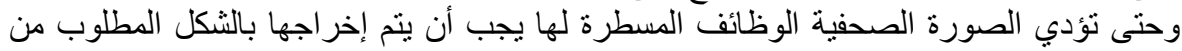

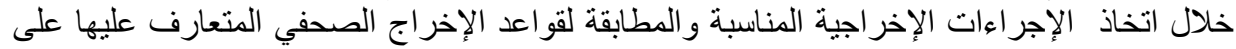

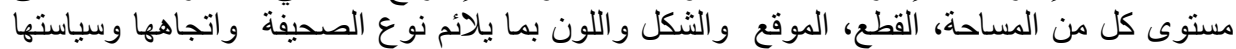

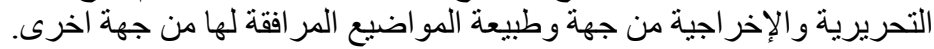

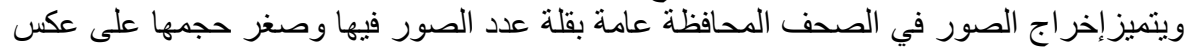

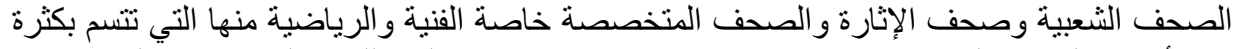

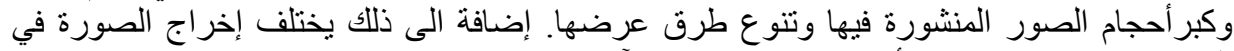

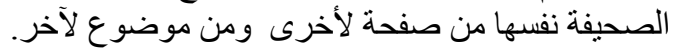

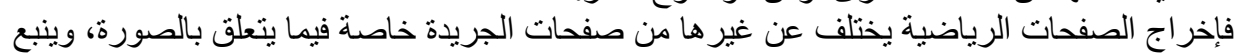
هذا الاختلاف من طبيعة الأخبار الرياضية ونوعية قرائها، وجو الحماس والإثارة الذي بميز بلئ النشاط 
الرياضي وهو ما ينطلب استخداما أكثر للصور وبأحجام أكبر وطرق عرض أكثر حيوية وحركة و أكثر

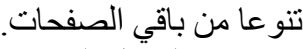

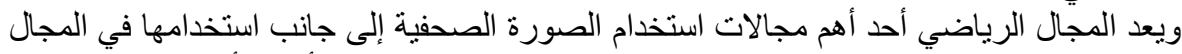

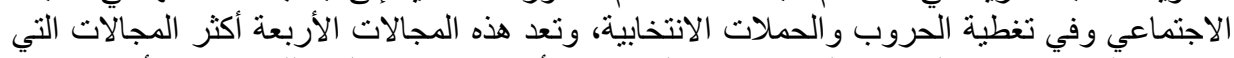

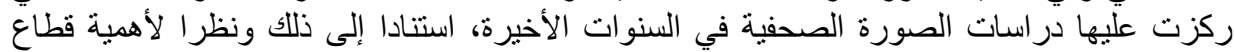

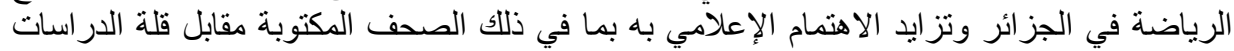

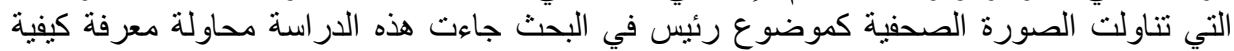

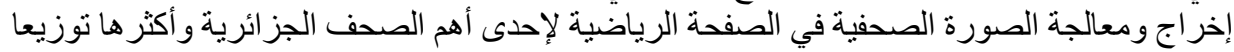
ومقروئية وهي صحيفة الخبر اليومية، مستندة في ذلك الكية إلى التساؤلات التالية التية: * * الجاتب الموضوعي: ويضم التساؤلات التالية:

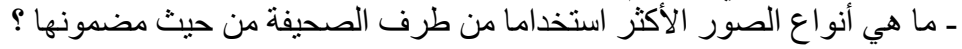

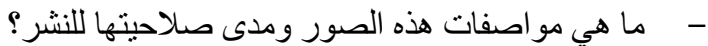
* الجانب ألثكلي: و يضم التساؤلات التالية:

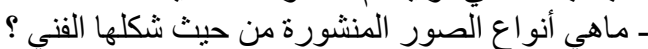

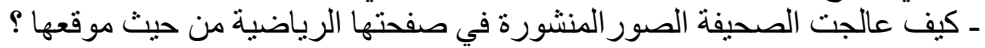

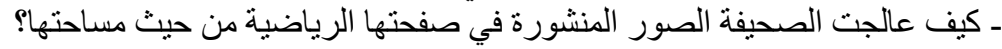

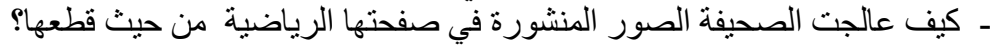

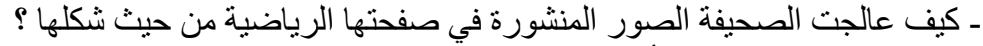

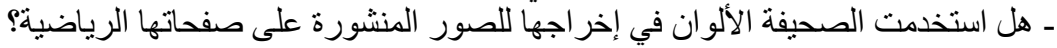

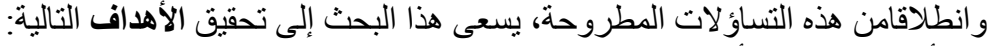

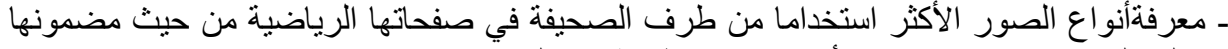

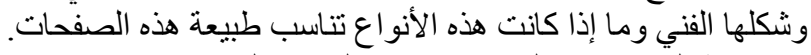

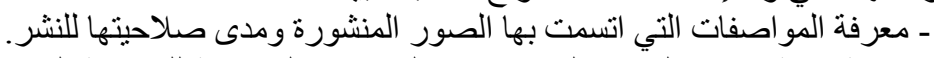

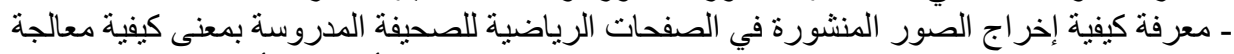

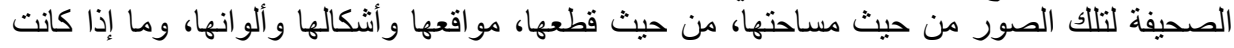

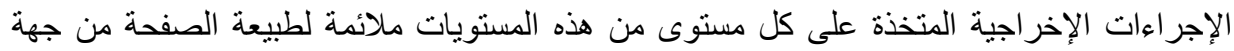

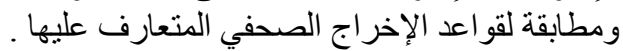

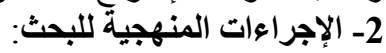

وسيتم هنا تحديد المجال الذي سيشمله هذا البحث و المنهج المنبع والأدوات التي سنستخدم لجمع البيانات فيه؛

2-2 1- 1 - مجتمع البحث وعينة الاراسة:

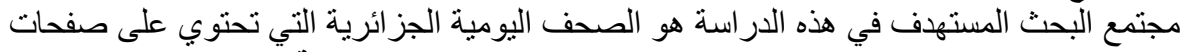

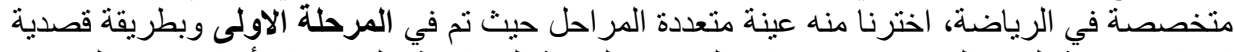

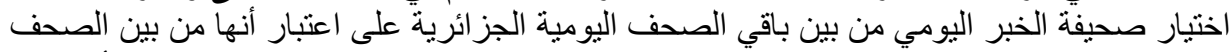

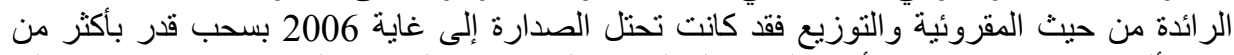

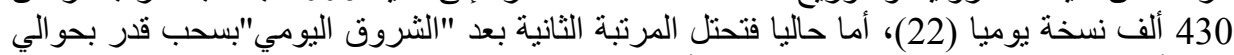

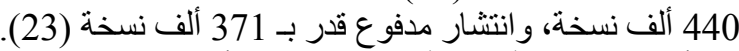

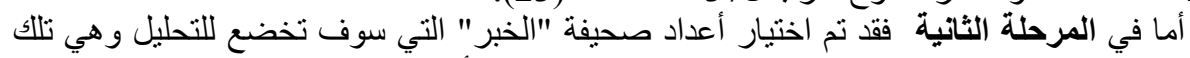

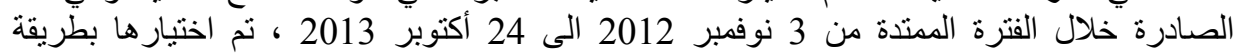

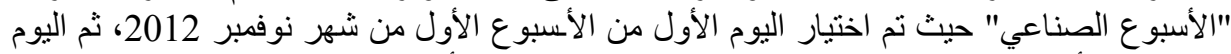

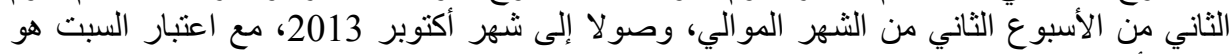
بداية الأسبوع الصناعي الصحفي و الخميس هو نهايته طبقا لما هو معمول به لألى الصحافة الجزائرية، 


\section{إخراج الصورة الصحفية في الصفحات الرياضية لليوميات الجزائرية \\ دراسة تحليلية لُصحيفة الخبر الصفات الرياضية لليوميات}

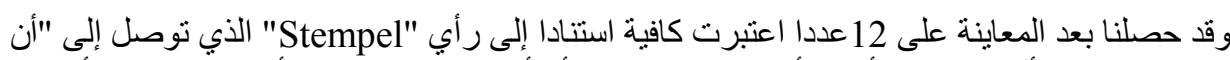

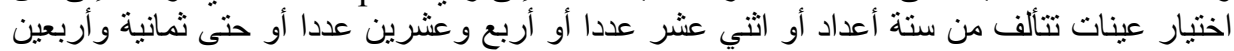

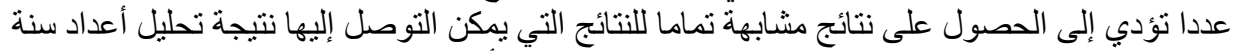

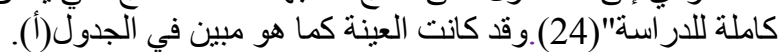

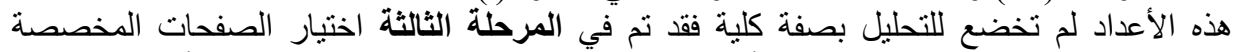

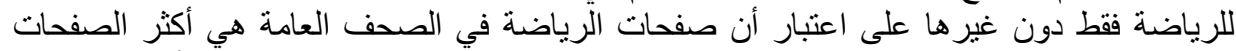

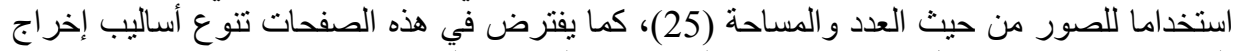

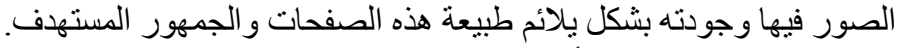
2-2-2 المنهج المستخدم و أداة جمع البيانات:

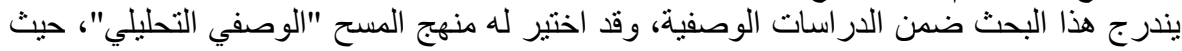

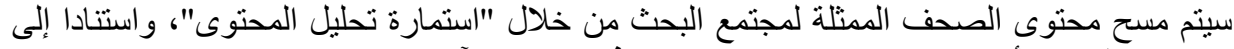
تساؤ لات البحث وأهدافه فقد تضمنت هذه الآستمارة فئتالتحليل الآتية:

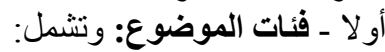
ـ نوع الصورة: وتحتوي على أنواع الصورة الصور المنشورة في الجريدة من حيث مضمونها والمنمثلة في:

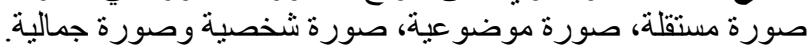

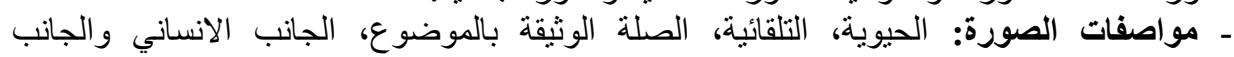

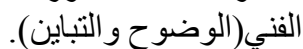

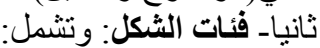

ـشكل نشر الصورة: ويعني شكل الصورة الفني وقد اعتمدنا على عدة أنشكال؛ صورة مفردة، سلسلة الصور وصور المشهر المتعاقب. - موقع الصورة: ويضم الفئات التالية:

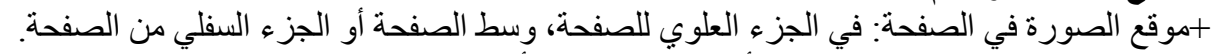

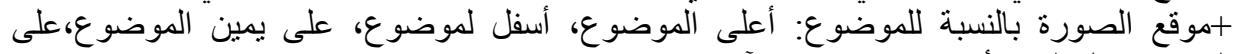

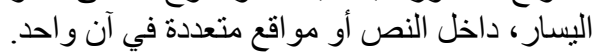

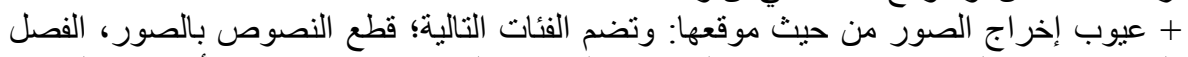

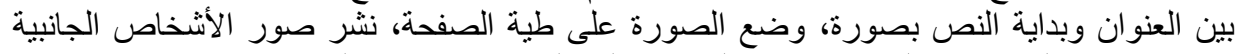

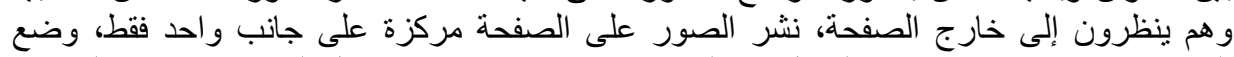

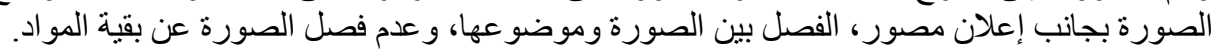
ـ مساحة الصورة: وتضم ثلاثث فئات؛

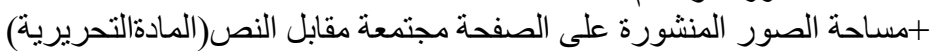

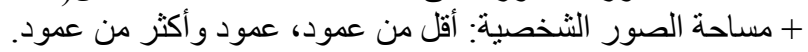

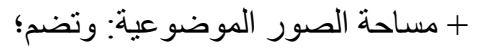

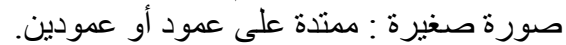
صورة متوسطة: ممتدة على ثلاثة أو أربعة أعمدة.

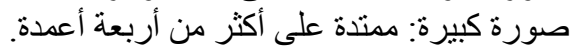

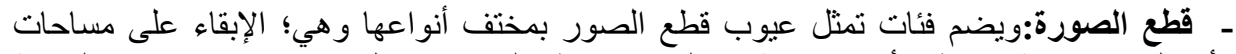

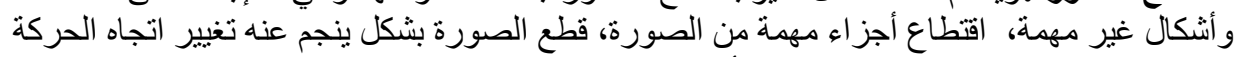

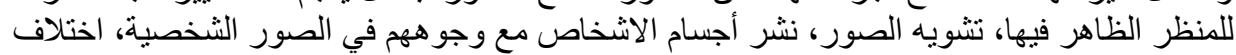

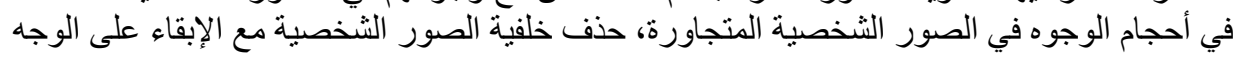
فقط في حدود الرقبة. 
ـ شكل الصورة الهنسي: ويضم الفئات التالية؛ مستطيل أفقي، مسنطيل عمودي، مربع، شكل

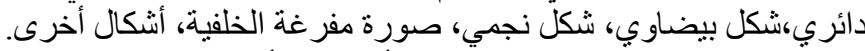

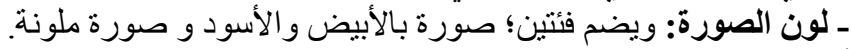

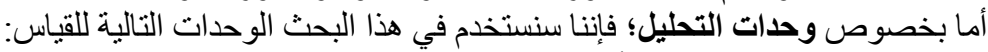

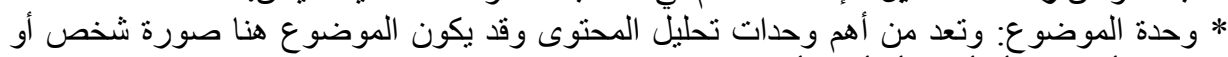

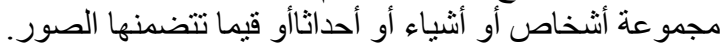

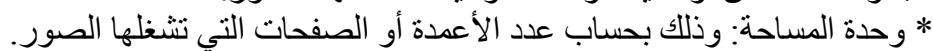

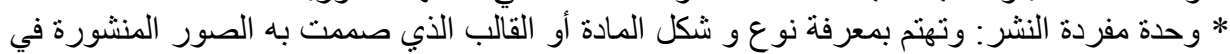
الصحيفة محل الدر اسة.

3-

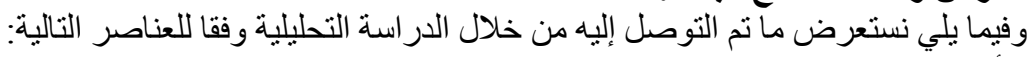
1-3 - 2-3 أنواع الصور:

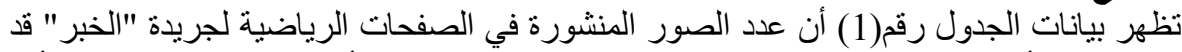

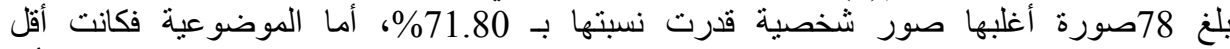

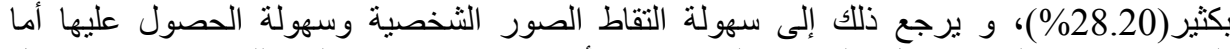

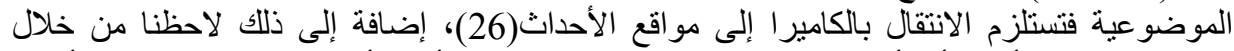

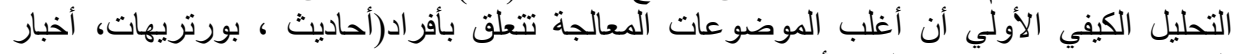

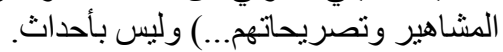

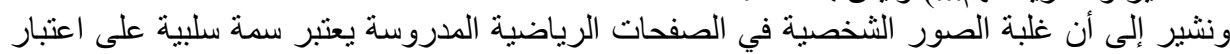

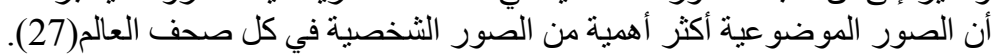
2-3-3 مواصفات الصور:

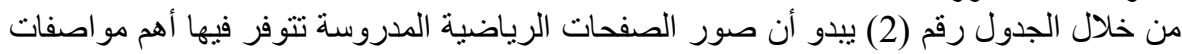

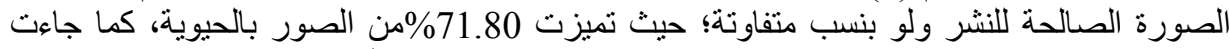

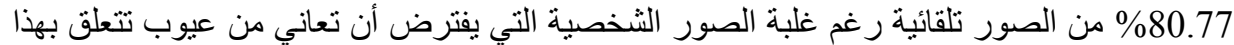

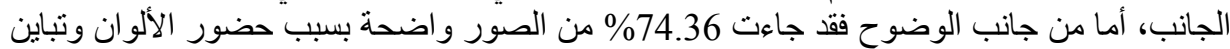

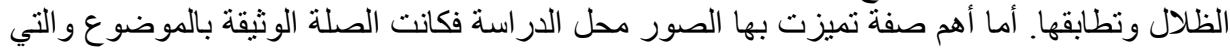

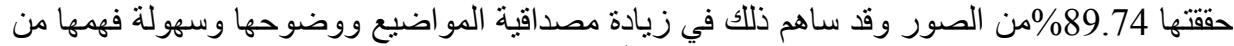

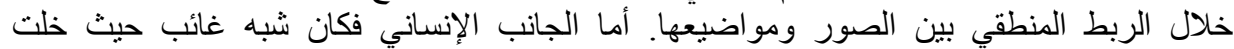
و61,54 من الصور المنشورة من القيم الإنسانية.

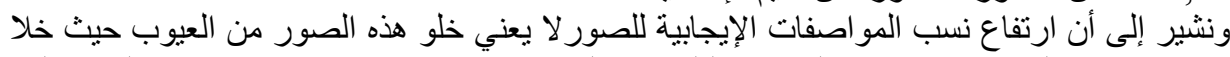

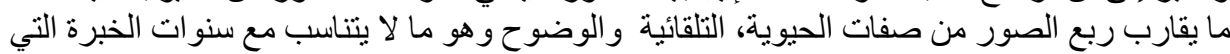

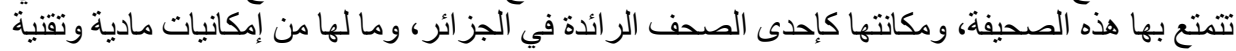
مقارنة بغير ها من الصحف الجز ائرية.

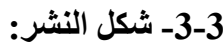

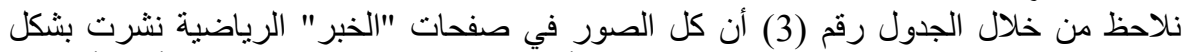

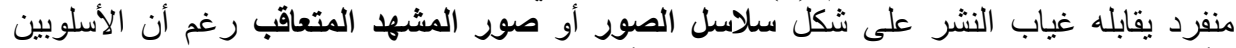

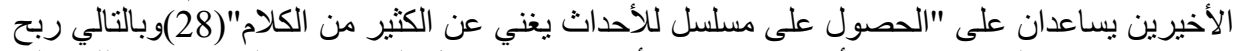

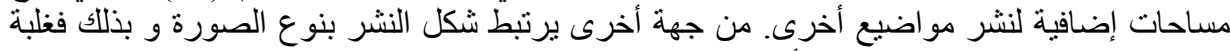

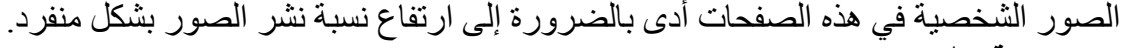
-3-3 مواقع الصور: وتتضمن مو اقع الصور على الصفحات، وموقعها بالنسبة لموضوعها، إضافة إلى عيوب إخر اج الصور

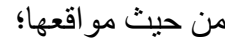




\section{إخراج الصورة الصحفية في الصفحات الرياضية لليوميات الجزائرية

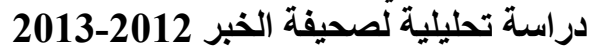

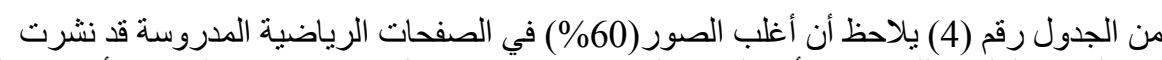

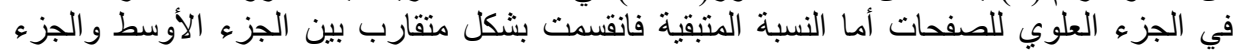

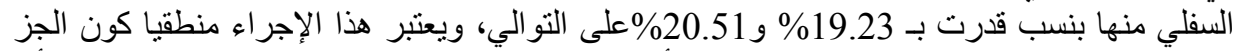

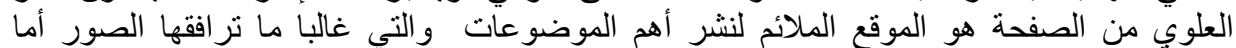

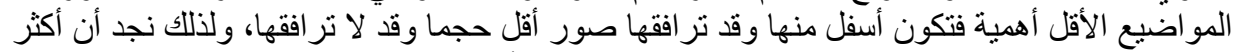

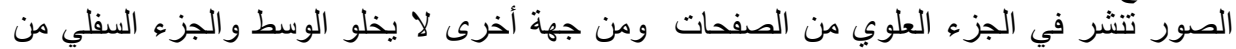

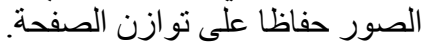

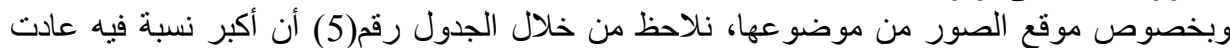

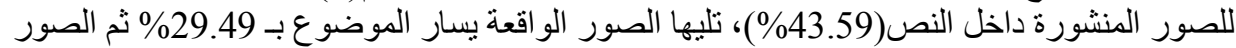

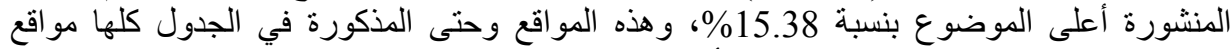

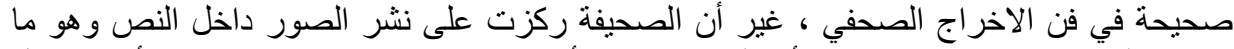
يحبذه "الصناوي" (29) حيث يرى أن الصورة يجب أن تنشر قريبة من موضوعها وإذا أمكن داخل

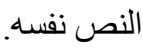

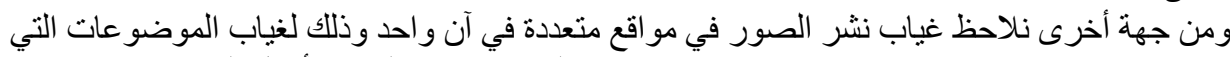

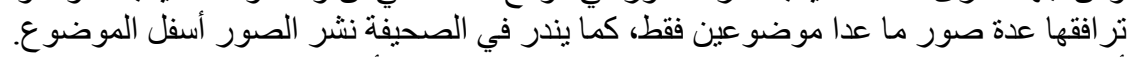

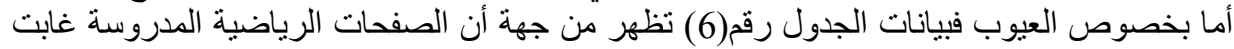

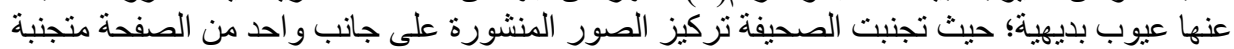

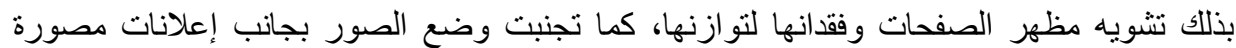

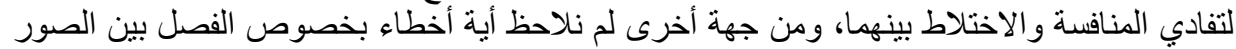

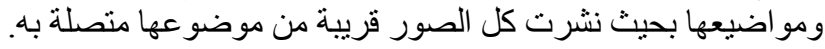

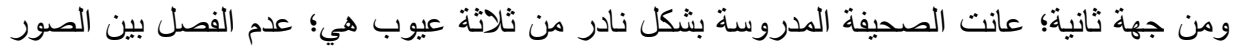

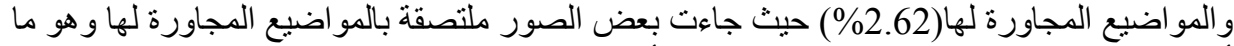

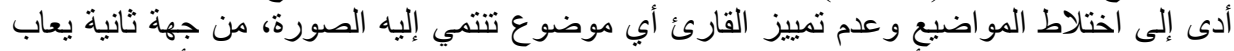

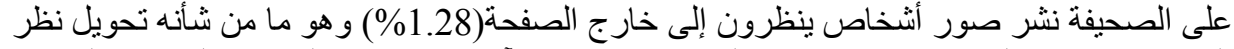

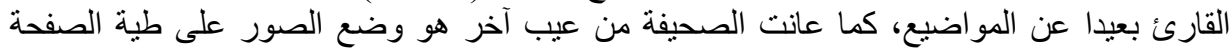

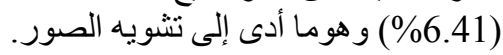

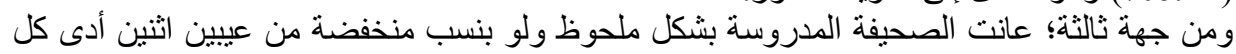

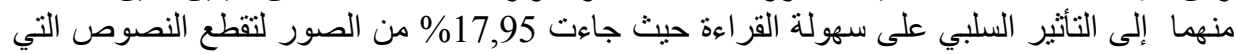

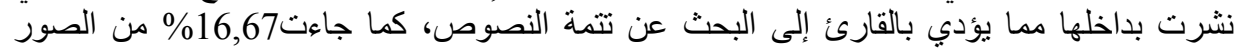

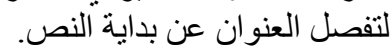

-5-3-3 مساحة الصور:

وتتضمن المساحة الإجمالية للصور مقابل النص، مساحة الصور الثخصية ثم مساحة الصور

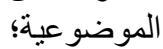

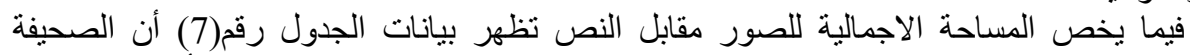

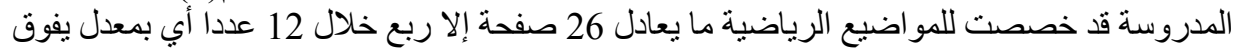

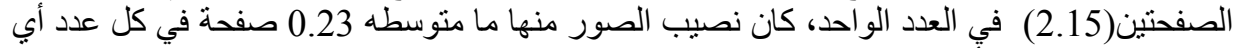

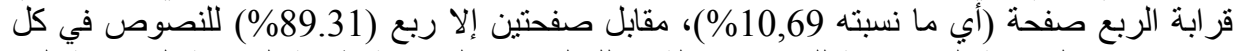

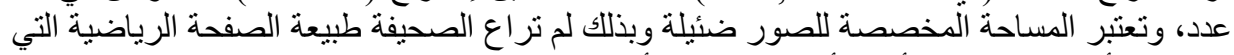

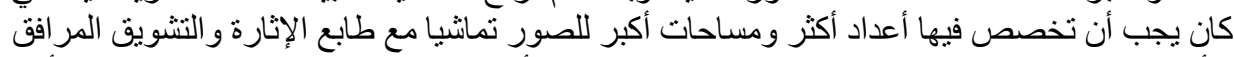
للأنشطة الرياضية، إضافة إلى ذلك لم تستغل الصحيفة كبر أحجام الصور كوسيلة لكيلة لجذب الانتباه و التأثير

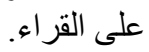




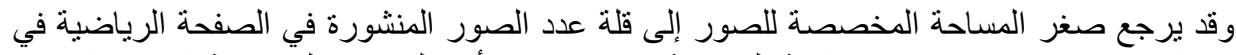
حد ذاته، و هو ما لا يتناسب مع مكانة الصحيفة باعتبار ها من أهم الصحف الجز الئرة الئرية ذات الامكانيات

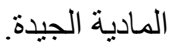

وبخصوص مساحة الصور الثخصية توضح بيانات الجدول رقم(83) أن أن أغلبية الصور الثخصية

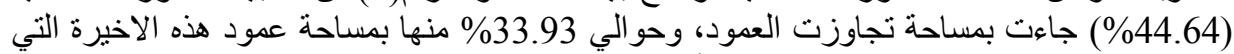

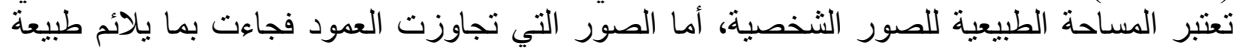

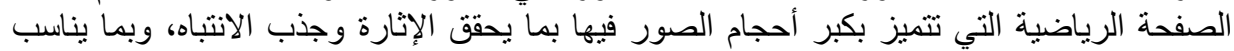

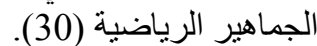
أما الصور بمساحة أقل من العمود فجاءت نسبتها مرتفعة رغم أنها أقلية وهو ما ساهم في قلة وضوحها وضعف تأثير ها.

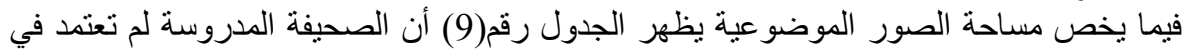

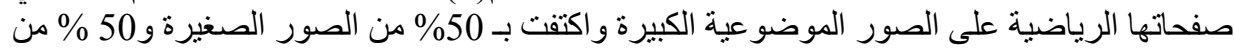

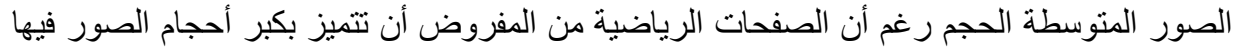

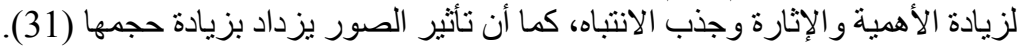

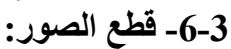

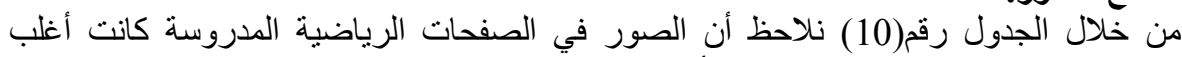

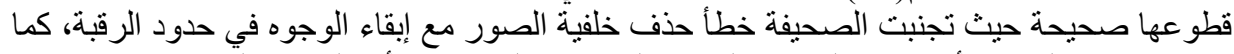

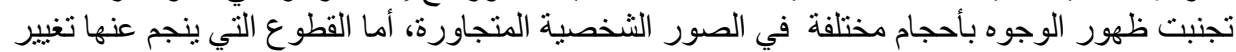

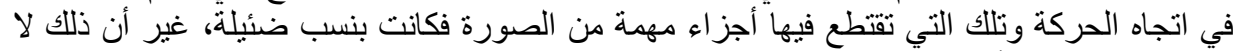

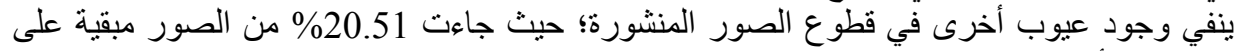

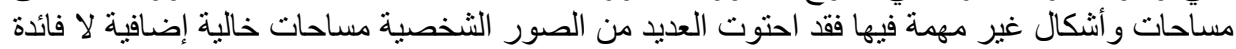

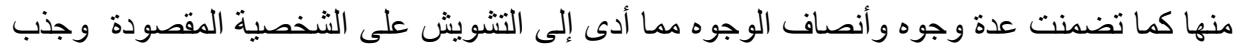

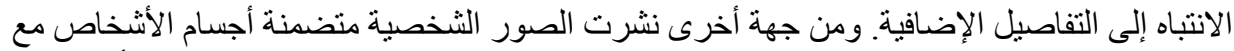

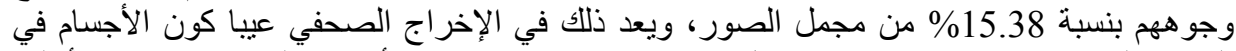

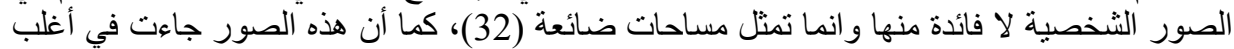

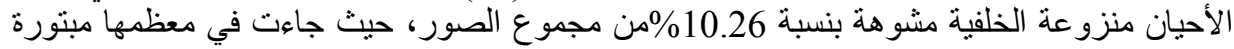

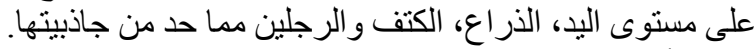

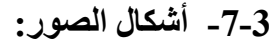

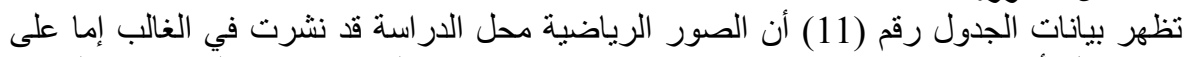

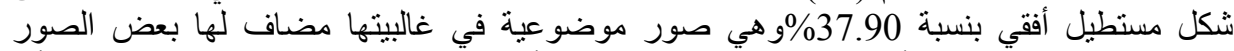

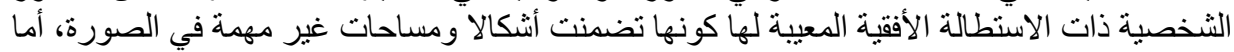

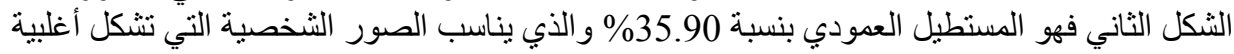
في الصفحات الدروسة والئ هو ما يفسر ارتفاع هذه النسبة.

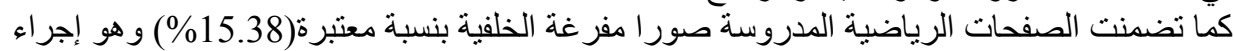

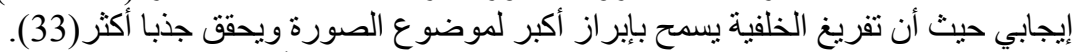

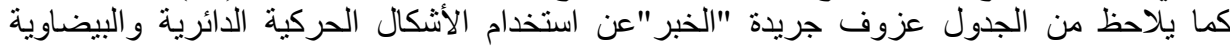

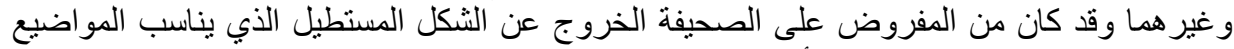
الجادة في باقي الصفحات واستخدام أنكال تنتاسب المواضيع الخروج الرياضية الحيوية الحركية والمثيرة.

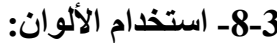

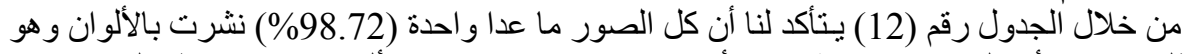
المطلوب حيث أن الصور رياضية كانت أو غير ها يفترض نشرها ها بالألوان حتى تحافظ على واقعيتها 


\section{إخراج الصورة الصحفية في الصفحات الرياضية لليوميات الجزائرية \\ دراسة تحليلية لُصحيفة الخبر الصفات الرياضية لليوميات}

و على شدة جذبها للانتباه وتأثيرها(34)، كما أن الصور الرياضية المنشورة بالألوان من شأنها أن تضيف للصفحة الكثير من الحيوية بما يناسب إنارة الأحداث الرياضئ الرياضية.

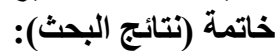

سعت هذه الدراسة إلى معرفة كيفية إخراج الصور في الصفحات الرياضية للخبر اليومي، وقد توصلنا بعد الار اسة التحليلية إلى النتائج التالية:

- لم تهتم جريدة "الخبر " بالصور الموضو عية رغم الهميتها حيث تعتمد في البنية الثكلية لصفحاتها

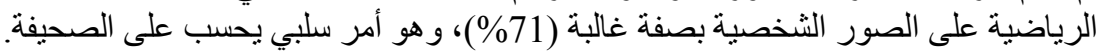

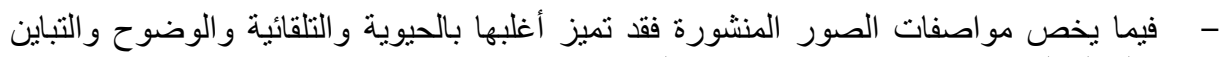
و الصلة الوثيقة بموضو عها في حين كان الجانب الإنساني غائبا فيها.

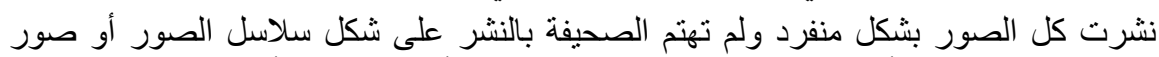

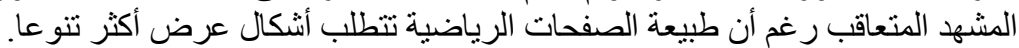

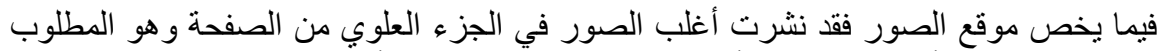

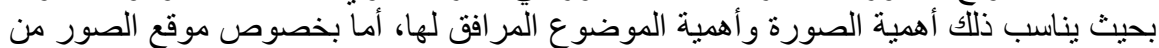

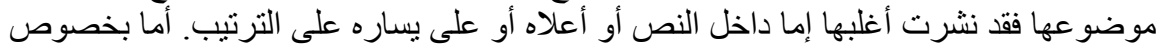

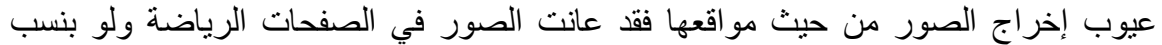

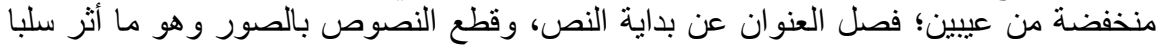
على سهولة القر اءة.

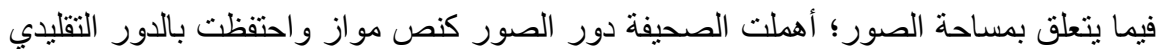

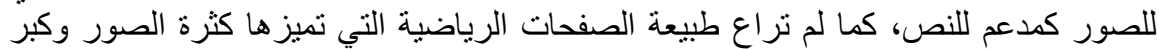

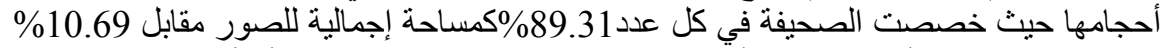

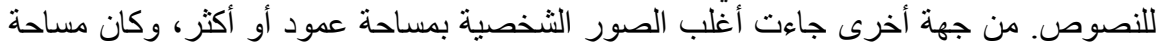

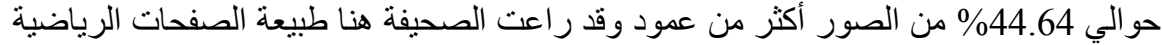

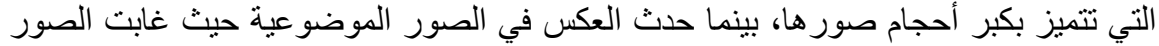

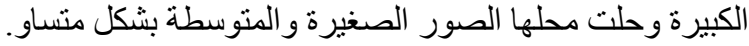

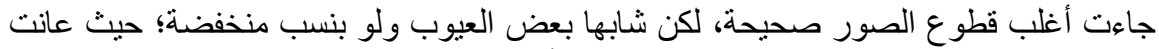

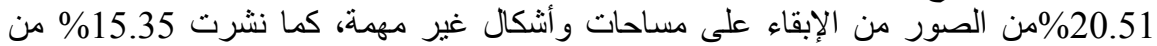

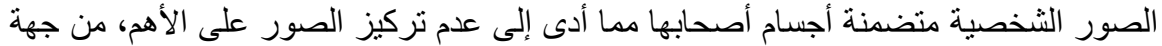

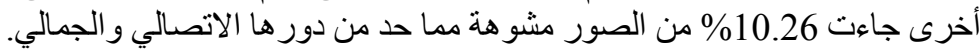
وبخصوص أثنكال الصور؛ عزفت الصحيفة عن استخدام الأثكال الحركية (الدائرية و البيضاوية التهاية)

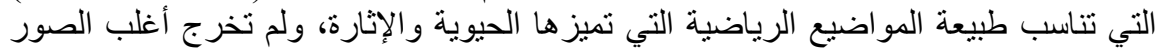

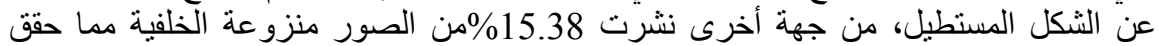

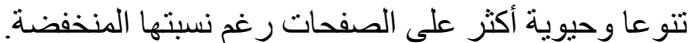

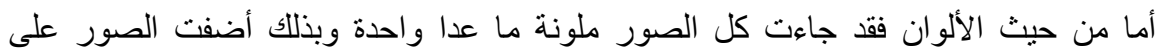

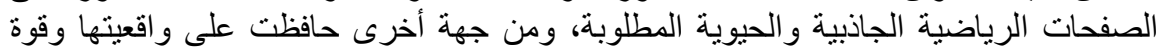


2- سعيد الغريب النجار: التصوير الصحفي الفيلمي والرقمي، ط1، الدار المصرية اللبنانية، القاهرة، . 2008

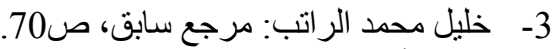

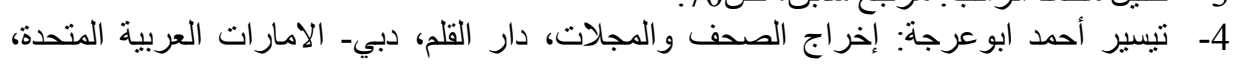

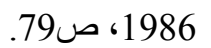

5- سعيد الغريب النجار: الإخراج الصحفي، ط1، الدار المصرية اللبنانية، القاهرة، 2001، ص

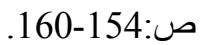

6- أحد حسين الصاوي: طباعة الصحف وإخراجها، الدار القومية للطباعة، القاهرة،1956، ص180.

7- علي نجادات: الإخر اج الصحفي- اتجاهاته، مبادئه و العو امل المؤثرة فيه و عناصرهـ، ط1، حمادة

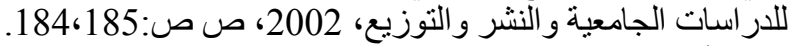

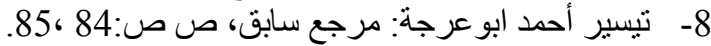

- الاتحاد العام للصحفيين العرب: سكرتير التحرير ، الاتحاد العام للصحفيين العرب، بغداد، 1981،

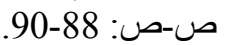
- كمال عبد الباسط الوحيثي: أسس الإخراج الصحفي "دراسة تطبيقية على الصفحات الأولى في لئي

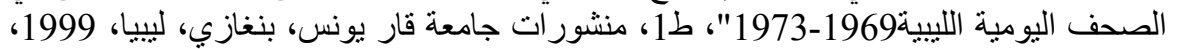
ص-ص:-400-400-405.

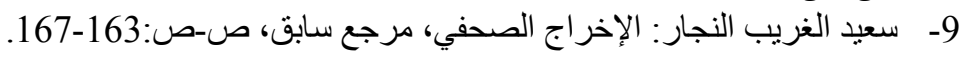
- - أنرفف محمود صالح: إخراج الصحف العرب، العربية الصادرة بالإنجليزية، دار الطباعي العربي، دون

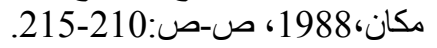

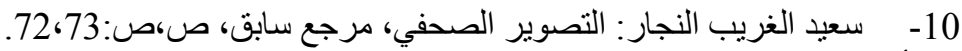

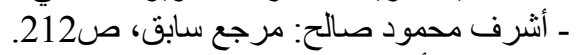

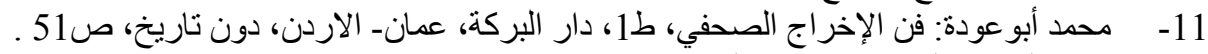

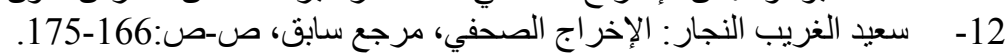

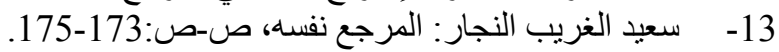

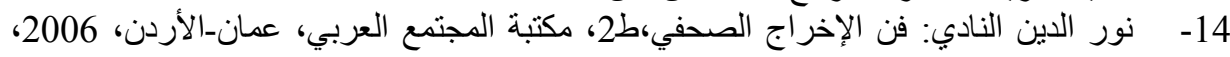

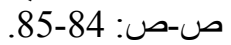
15- سعيد الغريب النجار : الإخر اج الصحفي، مرجع سابق، ص132

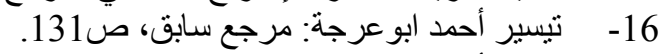

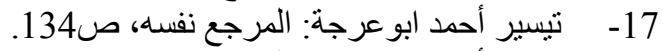

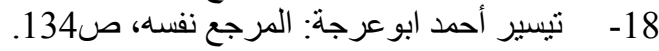

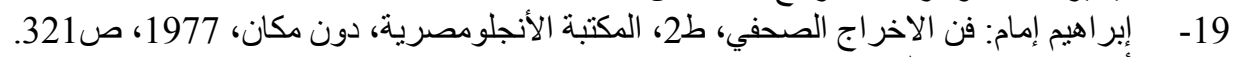

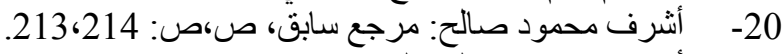

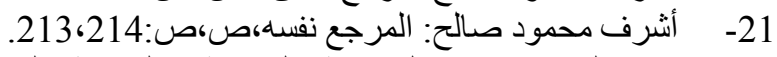

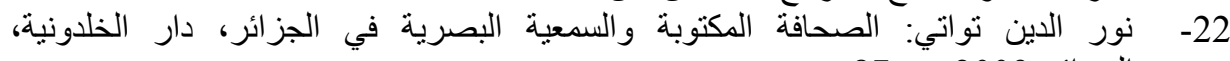

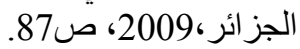
Association pour le contrôle de la diffusion des media (OJD):book 2012 presse payantegrand public" www.ojd.com/book/export/232 / 19/04/2013. علي نجادات: "الاتجاهات الإخراجية للصفحة الأولى في الصحف الأردنية الأسبو عية (دراسة الئة

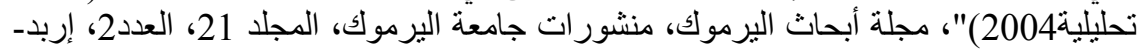

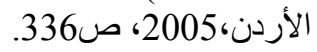


25- أشرف محمود صالح: مرجع سابق، ص،ص: إن: 214،213.

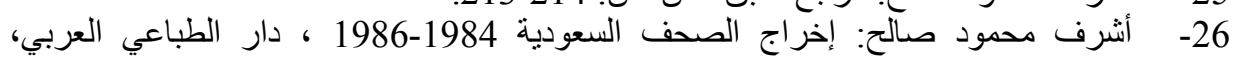

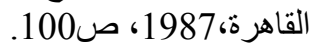

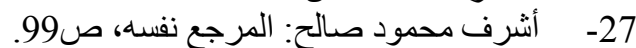

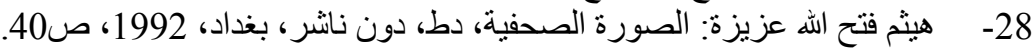

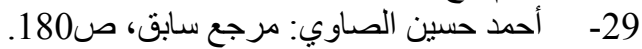

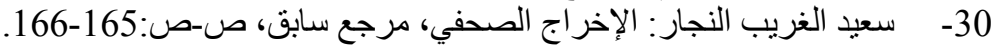

Edmund Arnold: Designing the Total Newspaper, Harper and Row -31

Publishers, New York 1980,p101-102

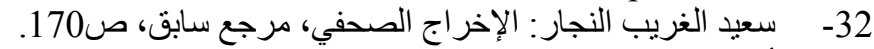

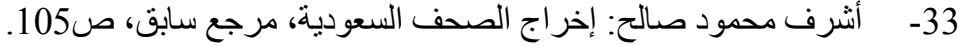

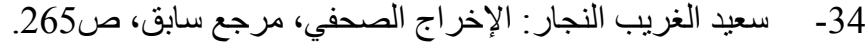

\begin{tabular}{|c|c|c|c|}
\hline \multicolumn{4}{|c|}{ جدول (أ): يمثل عينة الدر اسة } \\
\hline اليوم (التاريخ) & الأسبوع & الشهر & 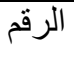 \\
\hline السبت 2012/11/03 & 1 & نوفمبر & 1 \\
\hline الأحد 2012/12/09 & 2 & 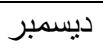 & 2 \\
\hline الاثثين 2013/01/21 & 3 & جانفي & 3 \\
\hline الثلاثاء 2013/02/26 & 4 & فيفري & 4 \\
\hline الأربعاء 2013/03/06 & 1 & مارس & 5 \\
\hline الخميس 2013/04/11 & 2 & أفريل & 6 \\
\hline السبت 2013/05/18 & 3 & ماي & 7 \\
\hline الأحد 2013/06/23 & 4 & جوان & 8 \\
\hline الاثثين 2013/07/01 & 1 & جويلية & 9 \\
\hline 2013/08/13 الثتلاثاء & 2 & أوت & 10 \\
\hline الأربعاء 2013/09/18 & 3 & سبتمبر & 11 \\
\hline الخميس 2013/10/24 & 4 & أكتوبر & 12 \\
\hline
\end{tabular}

جدول رقم(1): يمثل أنواع الصور المنثورة على الصفحات الرياضية لجريدة الخبر

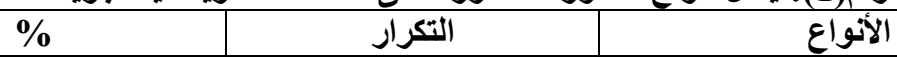


أحلام باي

\begin{tabular}{|c|c|c|}
\hline- & - & صورة مستقلة \\
\hline$\% 28.20$ & 22 & صورة موضو عية \\
\hline$\% 71.80$ & 56 & صورة شخصية \\
\hline- & - & صورة جمالية \\
\hline$\% 100$ & 78 & المجموع \\
\hline
\end{tabular}

جدول رقم(2): مواصفات الصور المنشورة على الصفحات الرياضية لجريدة الخبر

\begin{tabular}{|c|c|c|c|c|c|c|}
\hline \multirow{2}{*}{\multicolumn{2}{|c|}{ المجموع }} & \multirow{2}{*}{\multicolumn{2}{|c|}{$\gamma$}} & \multirow{2}{*}{\multicolumn{2}{|c|}{ نعم }} & \multirow{3}{*}{ المواصفات } \\
\hline & & & & & & \\
\hline$\%$ & ت & $\%$ & $ت$ & $\%$ & $ت$ & \\
\hline$\% 100$ & 78 & 28.20 & 22 & 71.80 & 56 & الحيوية \\
\hline$\% 100$ & 78 & 19.23 & 15 & 80.77 & 63 & التلقائية \\
\hline$\% 100$ & 78 & 10.26 & 8 & 89.74 & 70 & الصلة الوثيقة بالموضوع \\
\hline$\% 100$ & 78 & 61.54 & 48 & 38.46 & 30 & الجانب الانساني \\
\hline$\% 100$ & 78 & 25.64 & 20 & 74.36 & 58 & الوضوح و التنباين \\
\hline
\end{tabular}

جدول رقم (3): الثكل الفني للصور المنشورة على الصفحات الرياضية لجريدة الخبر

\begin{tabular}{|c|c|c|}
\hline$\%$ & التكرار & شكل النشر \\
\hline$\% 100$ & 78 & صورة مفردة \\
\hline - & - & سلسلة صور \\
\hline - & - & صور المشهد المتعاقب \\
\hline$\% 100$ & 78 & المجموع \\
\hline
\end{tabular}

جدول رقم (4):موقع الصور المنثورة على الصفحات الرياضية لجريدة الخبر(على الصفحات نفسها)

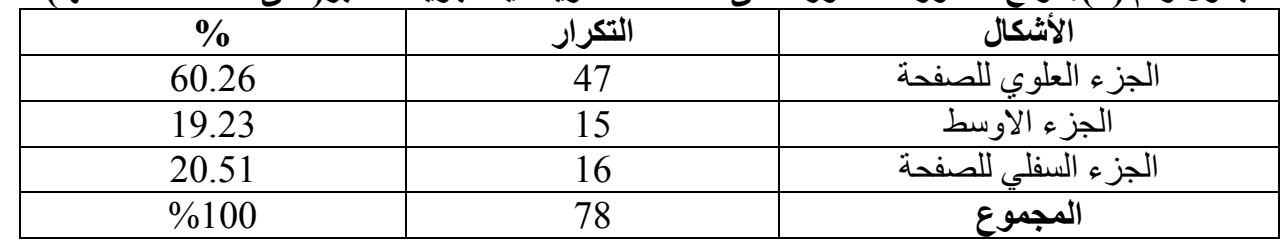

\begin{tabular}{|c|c|c|}
\hline$\%$ & التكرار & الموقع \\
\hline 15.38 & 12 & أعلى الموضوع \\
\hline 2.56 & 2 & أسفل الموضوع \\
\hline 8.97 & 7 & يمين الموضوع \\
\hline 29.49 & 23 & يسار الموضوع \\
\hline 43.59 & 34 & داخل النص \\
\hline - & - & مو اقع متعددة في آن واحد \\
\hline$\% 100$ & 78 & المجموع \\
\hline
\end{tabular}


إخراج الصورة الصحفية في الصفحات الرياضية لليوميات الجزائرية

دراسة تحليلية لتصحيفة الخبر 2013-2012

جدول رقم(6): عيوب إخراج الصور من حيث موقعها.

\begin{tabular}{|c|c|c|c|c|c|c|}
\hline \multicolumn{2}{|c|}{ 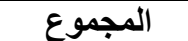 } & \multicolumn{2}{|c|}{$\bar{y}$} & \multicolumn{2}{|c|}{ نعم } & \multirow[t]{2}{*}{ العيوب } \\
\hline$\%$ & $ت$ & $\%$ & $ت$ & $\%$ & ت & \\
\hline$\% 100$ & 78 & 82.05 & 64 & 17.95 & 14 & قطع النصوص بالصور \\
\hline$\% 100$ & 78 & 83.33 & 65 & 16.67 & 13 & الفصل بين العنوان وبداية النص \\
\hline$\% 100$ & 78 & 93.59 & 73 & 6.41 & 5 & وضع الصورة على طية الصفحة \\
\hline$\% 100$ & 78 & 98.72 & 77 & 1.28 & 1 & صور أنثخاص جانبية ينظرون خار ج الصفحة \\
\hline$\% 100$ & 78 & 100 & 78 & - & - & تركيز الصور المنشورة على جانب واحد من \\
\hline$\% 100$ & 78 & 100 & 78 & - & - & وضع الصورة بجانب إعلان مصور \\
\hline$\% 100$ & 78 & 100 & 78 & - & - & الفصل بين الصورة وموضو عها \\
\hline$\% 100$ & 78 & 97.44 & 76 & 2.56 & 2 & عدم الفصل بين الصور وبقية المواضيع \\
\hline$\% 100$ & 78 & 100 & 78 & - & - & 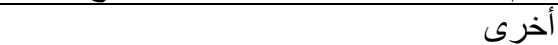 \\
\hline
\end{tabular}

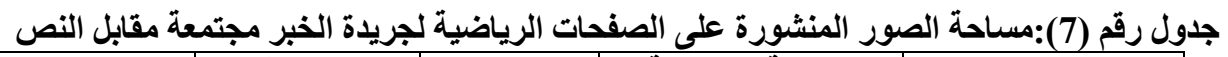

\begin{tabular}{|c|c|c|c|c|}
\hline $\begin{array}{c}\text { منوسط } \\
\text { النسب }\end{array}$ & الصفحات & $\%$ & المساحة(بالصفحة) & الفئات \\
\hline$\% 10.69$ & 0,23 & $\% 10.64$ & 2.74 & مساحة الصور \\
\hline$\% 89.31$ & 1.92 & $\% 89.36$ & 23,01 & مساحة النص \\
\hline$\% 100$ & 2,15 & $\% 100$ & 25.75 & الكليةتلصفيةات الرياتة \\
\hline
\end{tabular}

جلول رقم (8):مساحة الصور الثخصية المنشورة على الصفحات الرياضية لجريدة الخبر

\begin{tabular}{|c|c|c|}
\hline$\%$ & التكرار & المساحة \\
\hline 21.43 & 12 & أقل من عمود \\
\hline 33.93 & 25 & عمود \\
\hline 44.64 & 19 & أكثر من عمود \\
\hline$\% 100$ & 56 & المجموع \\
\hline
\end{tabular}

جدول رقم (9): مساحة الصور الموضوعية المنشورة على الصفحات الرياضية لجريدة الخبر

\begin{tabular}{|c|c|c|}
\hline$\%$ & التكرار & الفئات \\
\hline 50 & 11 & صورة صغير (1-2عمود) \\
\hline 50 & 11 & صورة متوسطة (3-4أعمدة) \\
\hline- & - & صورة كبيرة (أكبر من 4أعمدة) \\
\hline$\% 100$ & 22 & المجموع \\
\hline
\end{tabular}

جدول رقم(10): كيفيات قطع الصور المنشورة على الصفحات الرياضية لجريدة الخبر(العيوب)

القطوع


أحلام باي

\begin{tabular}{|c|c|c|c|c|c|c|}
\hline$\%$ & $ت$ & $\%$ & $ت$ & $\%$ & 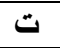 & \\
\hline$\% 100$ & 78 & 79.49 & 62 & 20.51 & 16 & الابقاء على مساحات و أشكال غير مهمة \\
\hline$\% 100$ & 78 & 96.15 & 75 & 3.85 & 3 & اقتطاع أجز اء مهمة من الصورة \\
\hline$\% 100$ & 78 & 98.72 & 77 & 1.28 & 1 & قطع نجم عنه تغيير اتجاه الحركة للمنظر الظاهر \\
\hline$\% 100$ & 78 & 89.74 & 70 & 10.26 & 8 & تشويه الصور \\
\hline$\% 100$ & 78 & 100 & 78 & - & - & الختلاف أحجام الوجوه في الصور الثخصية \\
\hline$\% 100$ & 78 & 84.62 & 66 & 15.38 & 12 & الشخر أجسبة الأشخاص مع وجو ههم في الصور \\
\hline$\% 100$ & 78 & 100 & 78 & - & - & حذف خلفية الصور مع الابقاء على الوجه في حدود \\
\hline$\% 100$ & 78 & 100 & 78 & - & - & أخرى \\
\hline
\end{tabular}

\begin{tabular}{|c|c|c|}
\hline \multicolumn{3}{|c|}{ جدول رقم(11):الشكل الهندسي للصور المنشورة في الصفحات الرياضبة } \\
\hline$\%$ & 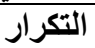 & الشكل \\
\hline 37.18 & 29 & مستطيل أفقي \\
\hline 35.90 & 28 & مستطيل عمودي \\
\hline 8.97 & 7 & 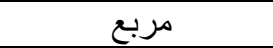 \\
\hline - & - & شكل دائري \\
\hline- & - & شكل بيضاوي \\
\hline- & - & شكل نجمي \\
\hline 15.38 & 12 & صورة مفرغة الخلفية \\
\hline 2.56 & 2 & أشكال أخرى \\
\hline$\% 100$ & 78 & المجموع \\
\hline
\end{tabular}

جدول رقم (12):استخذام الألوان في الصور المنشورة على الصفحات الرياضية لجريدة الخبر.

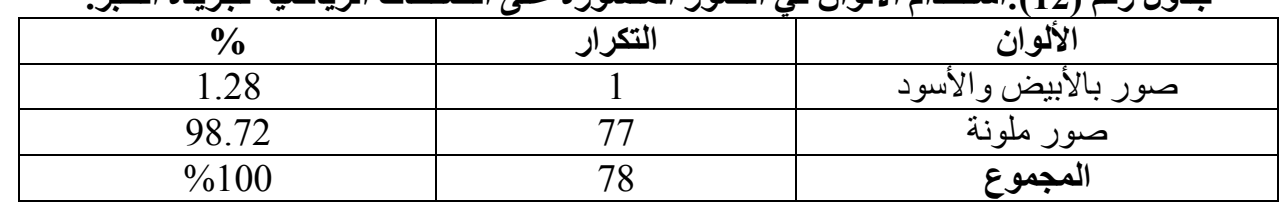

